\title{
Autoritarismo y democracia: Producción cultural, resistencia y pensamiento crítico
}

\author{
Ricardo Azuaga
}

Geográficamente distante de África, bastante más cerca de Europa y unido por un mismo continente a Estados Unidos, aquella América Latina del siglo XX no se parecía a ninguno de estos tres mundos. Con una alta población viviendo en pobreza, muchos de sus países sometidos por sanguinarias dictaduras y padeciendo gravísimas crisis económicas que los hacía altamente dependientes de alguna potencia, el subcontinente aún no vivía hambrunas como las africanas, pero poco familiares le resultaban los avances sociales que iban caracterizando a la Europa occidental y, muchos menos, aspiraba a acercarse al tan bien promocionado sueño americano. América Latina, con sus naturaleza exuberante, sus cielos luminosos o sus nieves eternas, su supuesto gusto por el baile, la guasa, por el bolero, el tango y, no se puede negar, los pequeños o enormes actos de corrupción, era diferente.

Sin embargo, el fin de siglo llegó con otros aires. Las dictaduras militares habían desaparecido en su mayoría, se juzgaba a los gobernantes y a sus cómplices mientras se intentaba reparar algunos de los dolorosos daños sufridos por las víctimas, ya algunas democracias parecían estables y unos cuantos países daban muestras de una clara recuperación económica. Nuevos aires que, sin embargo, dejaban algunas estelas peligrosas. Sobre todo aquella relacionada con la corrupción económica y social que, en muchos casos, sembró la desconfianza no hacia algunos individuos, sino hacia los partidos po- líticos y las instituciones. Una sensación que terminó convertida en desconfianza hacia la misma democracia.

Se había instaurado la antipolítica. Pero no solo eso. Como a principios del siglo XX, el mesianismo y el culto a la personalidad comienzan nuevamente a hacerse notar en buena parte de América del sur. En 1998, luego de sus dos intentos de golpes militares, en Venezuela gana las elecciones Hugo Chávez, gracias a un supuesto carisma que más bien era verbo incendiario, apoyado por muchos intelectuales, políticos, artistas y medios de comunicación. Hugo Chávez actúa como si fuera el pueblo y el Estado. Intrépido, histriónico y para nada apegado al protocolo, bendecido por unas rentas petroleras nunca antes vistas en el país, su discurso y su actitud van abriéndole paso en otros países del subcontinente donde también se ha instaurado la antipolítica y la desconfianza hacia el sistema democrático, así como en comunidades de otras latitudes que se identifican con el pensamiento antisistema y antiimperialista.

Sin despreciar el apoyo del presidente venezolano, llegan al poder Luiz Inácio Lula da Silva en Brasil (2003), Evo Morales en Bolivia (2005), Rafael Correa en Ecuador (2006), Daniel Ortega en Nicaragua (2007) y Néstor Kirchner en Argentina (2003), quien se convierte en presidente electo luego de la conveniente renuncia de Carlos Menem. Todos ellos, en mayor o menor medida, portadores de un discurso populista; de un modo u otro, cultores de su personalidad e impulsores de re- 
gímenes y estados que garantizarán su permanencia en el poder de manera más o menos arbitraria y autoritaria.

Ya en pleno siglo XXI, con la certeza de que las distopías de Phillip K. Dick o de cineastas como George Miller no están tan lejanas, el fantasma del autoritarismo y del control social va más allá de ese continente pintoresco que era América Latina. Amenaza sin disimulo al sistema de los Estados Unidos de América, se asoma en la actitud de ciertos gobiernos y líderes comunitarios en buena parte de Europa y ni hablar de los desmanes cometidos por gobiernos de África y Asia. De hecho, prácticamente desde su fundación, los países realmente democráticos son minoría en la Organización de $\mathrm{Na}$ ciones Unidas. Pero aún hay resquicios, pequeñas brechas por donde respirar.

Durante todo el siglo XX, América Latina supo poco de democracias. En cambio Venezuela, un país que hasta 1958 solo vivió unos amagos de libertad - especialmente entre 1945 y 1948 - , a partir de la caída del dictador Marcos Pérez Jiménez se convierte en un caso poco común para el resto de la región. Es casi la única democracia estable, con múltiples partidos reconocidos política y públicamente, con prosperidad económica y seguridad política.

Los focos de insurgencia guerrillera prácticamente desaparecen en 1969 y los líderes de izquierda se suman a la vida política y cultural del país al lado de las empresas públicas y privadas que invierten en publicaciones, obras monumentales y productos audiovisuales, mientras desde el gobierno se destinan fondos para la construcción de museos, fundación de editoriales o realización de películas. Y desde allí, desde ciertas producciones de la empresa privada o financiadas por el propio Estado, surgirán voces disidentes. Voces nostálgicas, a veces, como aquellas dedicadas a la historización estético emotiva - término propuesto por la historiadora del cine Ambretta Marrosu- de la lucha armada a través de novelas como País portátil de Adriano González León o Cuando quiero llorar no lloro, Miguel Otero Silva y su adaptación al cine por Mauricio Walerstein en 1972, hasta otras realmente disidentes o claramente críticas para con los gobiernos y presidentes de turno.
Pero el descontento social de la última década del siglo pasado, como hoy se manifiesta en otras latitudes, dio al traste con un proyecto que confió demasiado en su estabilidad económica, sustentada por un piso tan tembloroso como el del mercado petrolero, y por sus demostraciones de modernidad. Entonces, Venezuela también padece las consecuencias del culto a la personalidad, el autoritarismo y el control social.

En medio de toda esta inestabilidad global, regional y particular están los medios de comunicación y la producción cultural. De las crisis, las grandes empresas multinacionales, con su publicidad, sacan provecho. Desde finales de 2019 y más exactamente desde finales del primer trimestre de 2020 hemos visto cómo las industrias de la moda diseñan para nuevos cuerpos y diversos géneros mostrándolos como actos de responsabilidad social; las cadenas de televisión, ya sean de señal abierta, por pago o vía streaming, nos han bombardeado con ficciones, documentales o reportajes sobre plagas, pestes y pandemias y los portales periodísticos de todo el mundo, usando como vía la Internet, nos saturan de reportajes, estadísticas y noticias sobre lo que pasa y lo que vendrá. La ahora famosa «nueva normalidad» ya nos controla, decide qué podemos ver, escuchar, leer y decir, y nos impone unas formas de corrección que cercenan hasta la más mínima posibilidad de libertad de pensamiento por individual y privado que este sea.

Sin embargo, ya se dijo en párrafos anteriores, frente a la represión se manifiesta otra esencia liberal; ante el autoritarismo surgen voces democráticas y junto al sometimiento bárbaro se manifiesta la resistencia de la razón: el pensamiento crítico y la producción cultural.

\section{* * *}

Los cinco trabajos que se presentan a continuación pretenden ilustrar, a partir de diversas perspectivas y de cuatro manifestaciones culturales diferentes estética, espacial, étnica y temporalmente, el modo como las producciones culturales son creadas o pueden utilizarse como mecanismos de resistencia, impulsos de 
democratización, voces de disidencia o para promover el pensamiento crítico. Parten de lo regional —América Latina- con una manifestación artística de reconocido prestigio como es su teatro hasta llegar a experiencias aparentemente propias del ámbito privado - los videojuegos-, pasando por dos manifestaciones cinematográficas muy diferentes: por un lado, el cine empresarial y, por el otro, el cine de ficción con rasgos autorales.

Abre el dossier un artículo de la psicóloga colombiana Bibiana Pérez donde se aborda el tipo de memoria que construye la película de ficción colombiana Todos tus muertos (Moreno, 2011) sobre el conflicto sociopolítico colombiano actual, visibilizando dos dispositivos biopolíticos: la desaparición forzada y el narco-estado. Este análisis se llevará a cabo a la luz del concepto de «biopolítica» que propone el sociólogo y filósofo italiano Mauricio Lazzarato (1997), en el cual el público es el principal objeto de control en nuestra sociedad de la información contemporánea.

El segundo trabajo parte de dos perspectivas básicas que, desde el siglo XIX, han buscado definir la concepción de una identidad cultural latinoamericana: una sustentada en el llamado colonialismo heteróclito y otra, más reciente, basada en las reivindicaciones de los indígenas. La autora recorre este debate desde principios del siglo XX hasta nuestros días, en la búsqueda de posibles salidas para un reconocimiento de un ser cul- tural identificable por cada uno de los fragmentos que conforman los Estados nacionales en América Latina.

En tercer lugar, se analizan dos filmes hechos en Venezuela, dentro del llamado cine empresarial, realizados por una empresa estadounidense para la Creole Petroleum Corporation y para el Comité Fílmico de la Industria Petrolera. Es decir, se trata de cine producido por las compañías petroleras entre 1948 y 1949, cuando el país vivía uno de esos breves momentos de apertura democrática, y que siguen estrategias discursivas y propósitos muy distintos.

El cuarto trabajo toma como punto de partida el personaje rebelde, popularizado por algunas películas de Hollywood, pero sobre todo por el cine europeo, para establecer la relación entre aquél y formas de expresión más locales y pintorescas como el costumbrismo y el color local junto con la posibilidad, real o no, de lograr así un cine nacional de denuncia y disidencia.

Por último, un estudio que parte de un producto cultural de uso común en el ámbito privado, los videojuegos, pero que se enlaza con intereses colectivos como la educación en medios, el desarrollo del pensamiento crítico y de los procesos de diálogo. Partiendo de un estudio cualitativo y de campo, la investigadora explora las experiencias de dos adolescentes frente a videojuegos de diversos géneros y reflexiona sobre su uso en el aula de clases. 
